\title{
Organised Crime in South Africa since Transition to Democracy
}

\author{
Kholofelo A Mothibi ${ }^{*}$, Cornelis J Roelofse, Atlas H Maluleke \\ Department of Criminology and Criminal Justice, University of Limpopo, South Africa
}

Copyright $\subseteq 2015$ by authors, all rights reserved. Authors agree that this article remains permanently open access under the terms of the Creative Commons Attribution License 4.0 International License

\begin{abstract}
This paper presents extend of the spread of organised crime in South Africa. The purpose of the paper is to highlight how transition to democracy added fuel for the growth of organised crime in South Africa. Political changes in South Africa provided openings for criminals which had not existed previously. When apartheid ended, border controls were weakened, thus creating potential areas of operation for organised crime. The paper used secondary data, collected from various scholarly documents on organised crime in South Africa. Findings reveal that organised crime was transformed from a domestic to an international phenomenon and from a law and order problem to a national and international security threat. Organised crime is a major threat to social stability and economic growth. It is also viewed as a major impediment to good governance and security in Africa. Policing organised crime relies heavily on the ability of the police agencies to gather intelligence on groups, activities and individuals and their contacts. The paper draws conclusions from the findings and makes recommendations on measures that can be put in place to reduce organised crime problem in South Africa.
\end{abstract}

Keywords Organised Crime, Political Transition, Democracy, Syndicates

\section{Introduction}

The initial signs of organised crime in South Africa can be attributed to the so called Chinese Traid societies. The Chinese Traid had drawn the attention of the police during 1970s when they were involved in the shark fin trade, smuggling of products from endangered species such as rhino horn, and illegal gambling operations. According to Gastrow [1] in 1990, organised crime groups had led to the growing trend of the crime problem in South Africa. In respond to the organised crime problems, the police established a national Organised Crime Intelligence Unit.

The transitional phase of the political dispensation in
South Africa created, for a number of years, a policing vacuum. Comparative evidence suggests that organised crime syndicates develop most rapidly in periods of political transition, when government resources are concentrated in certain areas only and gaps materialize in which organised criminal groups may function.

Likewise, Shaw [2] reveals that the growth of organised crime in Russia has been a feature of political transition to democratic order. One of the most prominent cases in point is that of the former Soviet Union. The collapse of communist rule allowed the development of virtually thousands of criminal organisations involving current and former members of the establishment. In South Africa, comparable forces have also been taking place. Before the demise of the apartheid regime, South Africa was not considered to have had an organised crime problem. However, Shaw [2] gave the impression that the organised crime existed during the apartheid era although at a relatively low extent and diverse fashion. This was only partly true: in the Western Cape organised gangs had forged links with foreign criminal organisations in East Asia in order to obtain narcotics commonly known as mandrax. Scholars argued that these gangs were often used to target anti-apartheid activists in exchange for police turning a blind eye to their activities.

In addition, towards the late $1980 \mathrm{~s}$, racially based organised crime developed in the form of "Boer Mafia". This crime syndicate was involved in a variety of criminal activities mostly the smuggling of weapons and disruptions of the anti-apartheid opponents. In general, however, during the apartheid regime, organised criminal activities were poorly developed, given the fact that the country was cut off from the rest of the world because of its racial-based state policies. The arrival of democracy in the country heralded an increase in organised criminal activity. South African Police Services indicate that when apartheid ended, border controls were weakened, thus creating potential areas of operation for organised crime. Scholars point out that, similar problems also occurred at a time when transitional criminal operations were expanding, for example, East Asian, Nigerian and East European syndicates bought into 
local South African criminal operations and expanded them.

The World Justice Information Network News [3] state that authoritarian controls at point of entry into North America and most European states, Southern Africa's favourable position on the drug trafficking paths between the Far and Middle East, the Americas and Europe and its accessibility through land, sea and air made it a profitable area for prohibited business. Given these dynamics, a report by the World Economic Forum quoted Republic of South Africa as having an organised crime problem second only to Columbia and Russia. The advent of democracy in the Republic of South Africa (RSA) had a definite impact on policing. The transition from the apartheid regime to current democratic dispensation had premeditated priorities that left organised crime almost unattended as more persistent issues were pursued. This has created a sufficient opportunity for organised crime syndicates to establish their operations in South Africa.

In addition, Roelofse [4] writes that it is also believed that "the preoccupation of the state with structural changes such as the creation of the nine provincial governments, dismantling the Transkei, Bophuthatswana, Venda, and Ciskei state apparatus as well as those of the self-governing zones and the new local government initiatives allowed crime syndicates to go almost unchecked in the initial year of democracy".

Disturbingly, the growth of organised crime syndicates has caught South African law enforcement agencies unprepared. This is because the South Africa Police Services (SAPS) are struggling to address the scourge of organised crime, given that they do not yet have adequate technical expertise to cope with it. The aim of this paper is to present an overview on how the changeover from the previous political regime to the current democratic dispensation had given room for the spread of organised crime in South Africa. The exploration of the nature and extend of organised crime in South Africa since transition to democracy will be highlighted. Secondary data, journal and books were used to conduct this study.

\section{Organised Crime}

Within South Africa, there are a variety of definitions of organised crime. The Prevention of Organised Crime Act of 1998 (POCA) [5] is noticeably devoid of a clear definition. POCA does, however, list criminal activities that would be covered by the law, as well as offering fairly broad traits of membership to a criminal group. Importantly, there must be a group committing the crimes, and there are stipulations over the types of the crimes to be considered organised crime. The SAPS has relied on a variety of terms and definitions and often uses the South African Police Service Act 67 of 1995 as reference. The Act defines organised crime as 'a person, group of persons or syndicate acting in an organised fashion or in a manner which could result in substantial financial gain for the person, group or persons or syndicate involved' and 'the circumstances amounting to criminal conduct or an endeavour there to which requires national prevention or investigation or crime which requires specialised skills in the prevention and investigation thereof'. For purposes of this study organised crime has been taken to refer to a broad range of serious economic and organised crimes that could be punishable under POCA, including criminal activities that would traditionally be seen as "white collar crime' as well as crimes perpetrated by large 'street gangs'. I will use the term organised crime to describe the activities of organised criminals rather than referring to groups or networks. Using the abovementioned conceptualisation of organised crime allows for a greater understanding of contemporary organised crime, and can incorporate new crimes such as cyber crime, which do not fit the typical form of organised crime.

According to Goga [6] the term "organised crime" refers to any illegal acts committed by a criminal organisation or syndicate, working together to achieve a common goal usually to make money. Roelofse [4] defines organised crime as a business with all the inherent practices of planning, hierarchy, division of labour, intelligence, market research, organisational culture, discipline, and contracting, driven for profit and power but without legal and moral constraints. In this study, organised crime groups also include mobsters from Russia and Eastern Europe which are known for smuggling of weapons and drugs trafficking. However, organised crime syndicates from African and Asian countries are known to be involved in everything from prostitution and trafficking of people and drugs to pornography, financial scams, computer crimes, genocide, and terrorism. The Federal Bureau of Investigation [7] reveals that organised crime syndicates around the world makes about "one trillion US Dollars in profits annually. This study suggests that the high profit earn from organised has had an adverse effect on the spread of organised crime not only in South Africa but also in the world as a whole.

Organised criminals have viewed South Africa as best market place for illegal business given its weak boarder access control. Factors such as poverty and high unemployment rate in South Africa have also contributed greatly to the spread of organised crime in the country. Because of poverty and shortfalls in employment, affected citizens are forced to participate in organised crime when recruited. Moreover, in some places, criminals have infiltrated legitimate businesses and industries, such as construction and garbage disposal. The legitimate businesses are often used to launder money and help cover up illegal activities. Liddick [8], who uses the term attributes rather than elements, submits that the most frequently cited organised crime attributes are: hierarchy, rational profit through crime, use of force or threat, corruption of public officials, public demands for services, monopoly control of illegal markets, restricted membership, non-ideological, specialisation of work tasks, codes of secrecy and extensive planning. Singh lists them characteristics and lists organisational structure, durability over time and diversified 
interests.

Albanese [9] mentions the following characteristics: continuing organised hierarchy, rational profit through crime, use of force or threat, corruption to maintain immunity, public demands for services, monopoly over particular market, restricted membership, non-ideological, specialisation, code of secrecy and extensive planning. Roth [10] lists corruption, violence, continuity, structure, discipline, lack of ideology, multiple enterprises, rules and regulations, codes of conduct and sophistication. Finckenauer [11] lists ideology or lack thereof, structure/organised hierarchy, continuity, violence, restricted membership/bonding, illegal enterprises, penetration of legitimate businesses and corruption.

Richards [12] lists characteristics of organised crime groups or criminal organisations as used by the Criminal Intelligence Directorate of the Royal Canadian Mounted Police (RCMP). While corruption, discipline, infiltration, monopoly, motivation, violence, continuity, mobility and diversity are similar to those of Mallory [13] above, he includes some additional characteristics on the list. The additional characteristics are as follows: Protection of the organisation's leaders by separating them from the soldiers, cell from cell, and function from function; subversion of society's institutions and legal and moral value systems; has allowed entrenchment and refinement of criminal activities and practices.; sophistication in the use of advanced communication systems, financial controls, and operations; bonding of individual-to-individual, and individual-to-organisation, for solidarity and protection, often through complex initiation rites.

Caiden et al [14] point out that the 1976 United States Task Force on Organised Crime, approached the understanding of organised crime by attempting to eliminate what is not organised crime. It listed the following characteristics: Organised crime is a conspiratorial crime; has profit as its primary goal; it is not limited to illegal enterprises or unlawful services but includes sophisticated activities as well; it is predatory, using intimidation, violence, corruption and appeals to greed; its conspiratorial groups are well disciplined and incorrigible; it is not synonymous with the Mafia but knows no ethnic bounds; and, it excludes political terrorists, being politically conservative, not radical. Maltz [15] lists nine characteristics of organised crime, namely - corruption; violence; sophistication; continuity; structure; discipline; bonding ritual; multiple enterprises; and involvement in legitimate enterprises. Hagan [16] concludes that organised hierarchy, rational profit through crime, use of force or threat of force and corruption to obtain immunity are the characteristics that have been identified with some consensus. Amongst the criminal groups themselves, violence is dramatically more common as compared to violence perpetrated amongst ordinary citizens.

Carter's [17] characteristics include - an accumulation of profits; longevity; a structure to further the group's crime; use of violence to help in attaining goals; and ability to corrupt government officials, police officials and/or corporate officials. He however, went further to quote the elements of organised crime as viewed by the "Dutch's Centrale Recherche Informatiedienst (CRI)" - as any hierarchical structure; internal support and sanctions; money laundering; corruption and bribery of legal system officials; involvement in more than one illegal activity; organisations that hide behind front companies; criminal activities that cover a long period of time; and members who act violently against competitors. Nair [18] puts forward the characteristics of organised crime which he calls "essential elements of organised crime" as - connectivity; communality; continuity; hierarchy of command; hierarchy of control; leadership; insulation of the leadership; motive; monopoly; predatory; specialized support; division of labour; public protection; ruthless enforcement; protective measures; laundering; age factor; political links; conspiracy; merchants of death; and destruction. According to Marion [19], the best way to define organised crime is through a description of its characteristics. She submits the characteristics as - goal for profit; longevity; secrecy; violence; opportunistic behaviours; corruption; restricted membership; conspiracy; hierarchy; non-ideological goals; loyalty; monopolistic practices; and rules to be followed. The exploration of organised crime in South Africa since transition to democracy will be discussed below.

\section{Nature of the Transition of Organised Crime in South Africa}

Organised crime in South Africa can probably be traced back to Chinese Triads that were involved in illegal fishing and shark fin trade. Later on we saw the smuggling of abalone, drugs, weapons, humans, rhino horn and now increasing quantities of cigarettes. The number of new organised criminal groups that were identified in South Africa for the 2003/2004 - 2010/2011 financial years is as follows:

Table 1. Number of organised crime groups identified in South Africa

\begin{tabular}{|c|c|c|c|c|c|c|c|c|}
\hline Year & $\begin{array}{c}2003 / \\
2004\end{array}$ & $\begin{array}{c}2004 / \\
2005\end{array}$ & $\begin{array}{c}2005 / \\
2006\end{array}$ & $\begin{array}{c}2006 / \\
2007\end{array}$ & $\begin{array}{c}2007 / \\
2008\end{array}$ & $\begin{array}{c}2008 / \\
2009\end{array}$ & $\begin{array}{c}2009 / \\
2010\end{array}$ & $\begin{array}{c}2010 / \\
2011\end{array}$ \\
\hline No & 120 & 186 & 115 & 109 & 72 & 51 & 121 & 179 \\
\hline
\end{tabular}

Lebeya, in Roelofse et al [20] 
Table 1 show that the number of identified organised crime groups peaked in 2004/05 and then dropped dramatically to 51 in $2008 / 2009$. It then started to increase again to almost the same level of 2004/05. According to Venter in Albanese et al [21] there are about 125 (compared to 120 for 2003/04 in Table 1) active crime syndicates in the region, operating from west, central, east, and southern Africa. Trade takes place across borders and includes women and children as part of the operations, but often drugs and arms are included as well as counterfeit goods (including cigarettes). Policing organised crime relies heavily on the ability of police agencies to gather intelligence on groups, their activities and the individuals and their contacts. In South Africa, Goga [6] maintains the intelligence services in the Police are going through a crisis and this can be the reason for the new wave of the increase in organised crime groups. One should also take the Soccer World Cup into consideration as groups infiltrated South Africa with prospects of an increased demand for sex and drugs during that time.

Swart [22] posits that "a spike in organised crime can almost certainly be attributed to the paralysis is of the police's embattled crime intelligence unit." He reacted to the release of crime statistics that indicate that crimes normally committed by syndicates such as truck and car hijacking and aggravated robbery has increased. The trouble in the intelligence unit (suspension of Richard Mdluli former head of crime intelligence unit 2009 to 2012, arrests of Solly Lazarus former head of finance at the crime intelligence unit and Hein Bernard former deputy head of finance at the crime intelligence unit) was a serious setback in the fight against organised crime cannot afford. Of particular concern within the country have been the apparent links between organised crime, political figures and law enforcement. A prominent example of this was the case of former police commissioner Jackie Selebi (Former SAPS national police commissioner) who was sentenced to 15 years in prison for his corrupt relationship with convicted drug trafficker Glenn Agliotti. Similarly, Radovan Krejcir, the notorious Czech fugitive, was known to have a relationship with Joey Mabasa while he was head of Gauteng Crime Intelligence. Furthermore, Burger [23] argues that entire police departments are alleged to be corrupt, providing a variety of services to criminals, such as 'losing' dockets, and selling firearms and drugs. Burger as quoted by Swart [22], stating that “... a unit that should be at the centre of any crime-fighting initiatives but instead focuses on its internal battles and meddles in the political arena." The increase in identified organised crime groups does not augur well for prospects of reducing crime in general in South Africa and has the potential to open up new exploitations of which one is the illicit trading in cigarettes.

Goga [6] stipulates that after the transition to democracy many of these apartheid-era social and business links remained, and security personnel on both sides of the conflict were known to have made inroads in the private security business and in organised crime, using the same routes and markets that they had used in the past. The market also had an important effect on organised crime. It is argued that growing demand for narcotics across the globe, at the same time as many African states were gaining independence in the 1960s and 1970s, and dramatically changed the modus operandi of criminal groups. During these years, smuggling and illicit trade routes were established across Southern African borders but also as far afield as India. The late 1980s and 1990s saw an increase in foreign criminal groups within the country. These transnational groups included Asian syndicates that were prominent in wildlife-related crimes, West African criminals, who left their home countries due to political instability, and other groups, including Middle Eastern, Eastern European, Italian and Indian/Pakistani criminals. Local crime groups also became increasingly sophisticated and were able to network across the globe. In the Western Cape in particular, functioning cartels were formed. Newham [24] argues that towards the end of apartheid there was an identifiable surge in crime within the country, both organised and inter-personal. By the early 2000 s crime reached unprecedented highs, though it has decreased significantly over the last 15 years. Below is a brief summary on the few OC groups in South Africa.

\section{Main Organised Crime Groups in South Africa}

In 2000 the legal Chinese population of South Africa was estimated at 100,000, and Police estimated that the country was home to another 100,000 to 200,000 illegal Chinese. The Triad groups in RSA are mainly Cantonese and Mandirin speaking groups of which according to Gastrow [1] are:

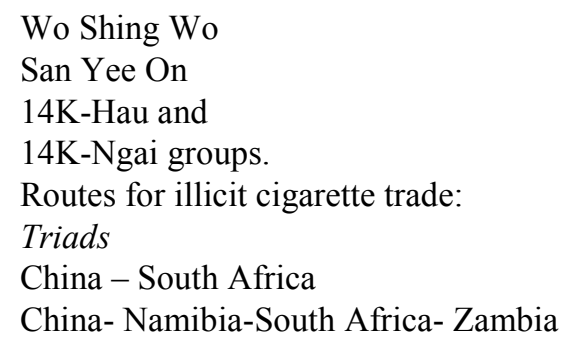

Middle East, Pakistani and Eastern European groups

UAE (Dubai) - South Africa,

UAE (Dubai) - Namibia - South Africa,

UAE (Dubai) - Namibia- Angola - Botswana/Namibia South Africa,

The Zimbabwean connection

Zimbabwe - South Africa - Mozambique

Stassen [25] quotes sources that say that approximately 55 percent of illegal cigarettes in South Africa originate from Zimbabwe, between 30 and 35 percent is manufactured locally and the rest originates from Middle Eastern countries.

\section{Structure and Hierarchy}

The diagram below portrays a comparison of structures in Somali pirates, South African organised crime and the Mafia. The Somali pirates operation has been dissected to give an 
idea of the sharing of income by different sections within the total operation. Profit sharing is a common practice within organised crime groups and their associates. It should be pointed out that legitimate cigarette producers (or at least some of their employees) can also be part of organised crime groups. The International Consortium of Investigative Journalists [26] reported the case of the murder of Tommy Chui who was to be a prosecuting witness against corrupt customs officials and a 100 million Hong Kong Dollar bribe in which three former executives of a big tobacco company were allegedly implicated. The same source also refer to a year- long investigation by the Center for Public Integrity that some tobacco companies have worked closely with companies and individuals directly connected to organised crime.

The involvement of even lawyers and political figures can be substantiated by several high profile cases of which the one in Louisiana in the USA is a good example. Lawyers used their connections in the Clinton administration to remove a prosecutor of a sales executive of a tobacco company for smuggling into Canada. Hence my insistence that organised crime can be distinguished from criminal groups and gangs by its connection to politicians and/or government officials.

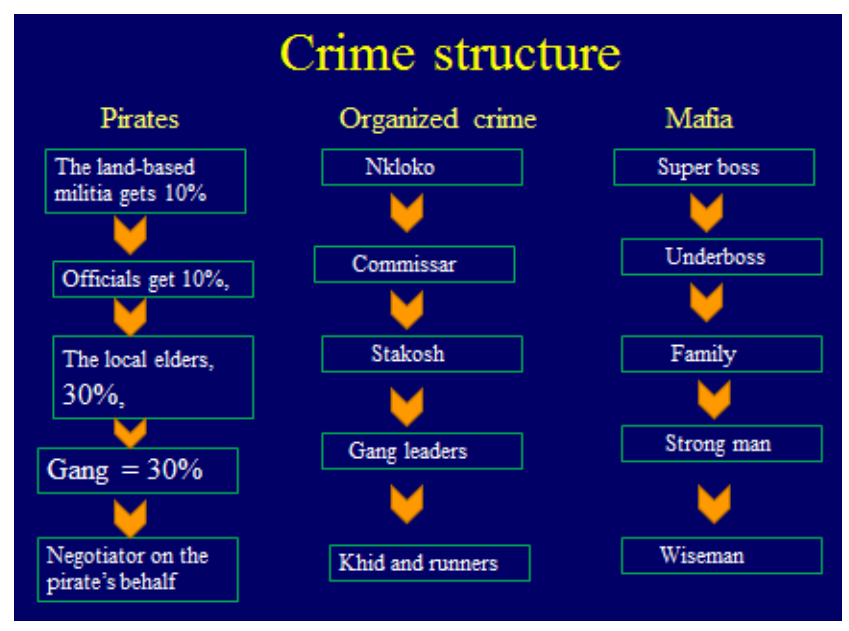

Swart [22] in Roelofse [20]

Diagram 1. Structure and income distribution of some organised crime groups

In the diagram above, the South African structure is portrayed as uncovered by the study by Swart [22] over a period of 14 years of studying crime systems, in instances infiltrating structures and using former operatives as sources. With reference to the way groups protect themselves made earlier, please note that in Diagram 2 below a gang raising a specified amount (R85000) at the time of the research is separated from the structure and can start its own operation. Roelofse [20] argues that such a group is detached from its former structure and is allowed to operate independently. Informal ties are kept and "contracting" for certain tasks may occur from time to time.

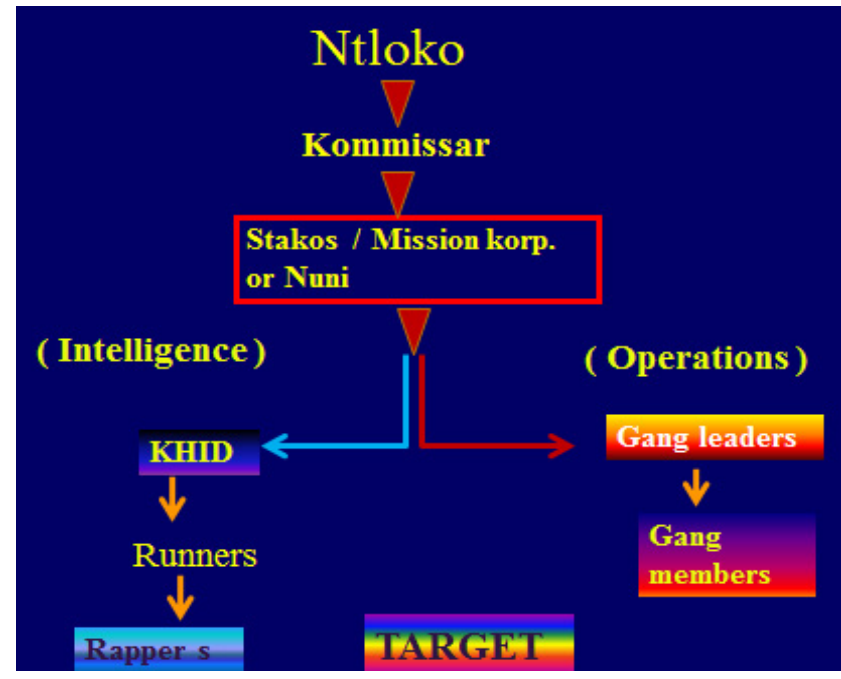

Swart [22] in Roelofse [20]

Diagram 2. South African groups

Roelofse [20] further writes that the names given to individuals and specific task groups are inherent to black organised crime groups in South Africa. Swart worked for a South African company as a consultant and uncovered a syndicate that infiltrated the company and through having members in strategic positions within the company, notably, recruitment, transport, procurement and fuel management, skimmed millions of Rand off the company per annum.

\section{Extend of Organised Crime in South Africa}

Minnaar [27] argues that a number of social and technological developments have also combined to create opportunities for organised crime. Advanced computer and communications technology facilitates the electronic funds-transfer system through which vast amounts of money can be transferred around the globe within seconds, and faxes and cellular phones can be encrypted, making it all but impossible to trace calls made from them. South African crime syndicates appear to opt for loose and shifting alliances and associations with other criminal groups or individuals, rather than for tightly knit organisations which rely solely on their own resources, to achieve their objectives. The growth of organised crime activities in South Africa was exacerbated by a number of factors. Firstly, after the first democratic elections in South Africa held in April 1994 the country opened up internationally and was exposed to global trends, both economically, politically and socially including crime influences, to a far greater extent than was the case prior to April 1994. This had an effect not only on the policing of the borders but also in the activities of crime syndicates for the smuggling in of drugs, illegal immigrants, firearms and other goods but also on the illegal export of stolen cars and endangered species. Secondly, the spin-offs of weak or poor controls at the borders/ports of entry are 
there for all to see, namely the proliferation of firearms, drugs, criminal activity by organised crime/international syndicates, the smuggling in of goods/contraband, fraud by way of not paying customs \& excise duties, round tripping of vehicles and other manufactured goods etc. This is not to say that lax controls and border porosity were the primary cause of these criminal activities but that they created the space which was exploited by all to pursue these criminal activities with greater ease and a degree of impunity. Thirdly, many of the crimes mentioned above are inter-related or linked in a symbiotic relationship. For example hijacked and stolen motor vehicles are increasingly smuggled out of the country and taken to points in neighbouring states for 'resale'. Funds thus generated are then used to purchase drugs, firearms and other contraband, which are then brought into South Africa and sold at enormous profits. Moreover, large numbers of firearms have over the years entered South Africa illegally. While in the 1980s and early 1990s these fuelled the political violence in South Africa and formed part of the struggle, post-April 1994 large quantities of these arms have found their way into use in various violent crimes such as bank robberies, vehicle hijacking, cash-in-transit robberies, minibus taxi-related violence and attacks on farmers. Although it is difficult to prioritise specific crimes the present flow of drugs, weapons and illegal movement of motor vehicles can be cited as possibly the most serious crime problems facing the country. All three somewhere along the chain are linked to cross border movement and the exploitation of current levels of border porosity (the so-called 'soft and leaky-border syndrome).

The extent of all these cross border criminal activities would not have been at such a level if there were no corrupt officials at the grassroots level. In this instance it extends to border control officials (border police and immigration officers to the customs and excise officers at the ports of entry) all over the country who are susceptible to bribery or assisting criminals and organised crime syndicates in obtaining false or fraudulent documents or of accepting forged documentation for a wide variety of goods or activities. A case in point here would be the activities of the Aliens Investigation Unit (AIU) of the SAPS. In September 1998 more than half of the 24-member National Aliens Investigation Unit was suspended on charges of corruption inter alia having sex with foreign prostitutes as payment for protecting them from deportation as illegal visitors.

In addition, Minnaar [27] suggested a number of factors that contribute to the growth of organised crime in South Africa and amongst others are renewed investor interest; South Africa's favourable geographical location on the major trafficking routes between the Far and Middle East, the Americas and Europe; South Africa's accessibility via land, sea and air routes. This can be supported that a number of unmonitored air strips exist close to our Northern borders which makes illegal and unnoticed border crossing very easy; a criminogenic market structure; unsaturated demand for and readily available illicit commodities such as drugs, arms, vehicles, endangered species products, and body parts exist; and the large-scale presence of illegal undocumented migrants notably from Southern African Development Community (SADC) countries, China, Taiwan, and Nigeria that are involved in organised crime adds fuel to the fire.

\section{Recommendations}

Based on the nature and extent of organised crime in South Africa, the authors recommend the following measures:

- Value-added technology to improve the monitoring of borders.

- Clever legislation to tackle sophisticated syndicates.

- Independent structures to control the large-scale borders, in particular in the northern borders.

- Valued-added technology to monitor and evaluate the issuing of passports, permits and visa.

- It is also important to consider the special investigations unit. This unit is involved in a number of wide-scale investigations into public service corruption, including investigations of government involvements in organised crime.

\section{Conclusions}

The weakening of the policing bodies of the state and regional environment in the democratic dispensation, change of policies in democratic dispensation, illegal issuing of passports, together with police corruption, have contributed to the development of organised crime in South Africa. Organised crime represents an enormous loss to the South Africa's Fiscus in terms of revenue, customs and excise dues through fraud, corruption, smuggling of goods, non-declaration or false values and forged manifests. Such a state of affairs has also impacted negatively on international investor confidence, not to mention other results such as firearm deaths in violent crime, health hazards of drug dependency and other social effects. Organised criminal organisations are generally characterised by absence of rigid structures and by their reliance on networks of criminals to assist in achieving their objectives.

\section{REFERENCES}

[1] Gastrow P. Traid Societies and Chinese Organised Crime in South Africa. Pretoria: Institute for Security Studies; 2001.

[2] Shaw M. Organised Crime in Post-Apartheid South Africa. Pretoria: ISS; 1998.

[3] World Justice Information Network (WJIN) News. Russia linked to arms and drugs in South Africa [News online] 1998 November 25 [cited 2012 Jun 10]. Available from http://www.wjin.net. 
[4] Roelofse CJ. Organised Crime in South Africa. Urbanization, Policing and Security: Global Perspectives. London: CRC Press; 2009.

[5] Prevention of Organised Crime Act, Act No 121 of 1998. [Cited 2013 Aug 12]. Available from http://www.acts.co.za/p revention-of-organised-crime-act-1998.

[6] Goga K. Responses to organised crime in a democratic South Africa. Pretoria: Institute for Security Studies; 2014.

[7] Federal Burea of Investigation. Organised Crime. [documents online] 2010 Oct 15 [cited 2012 Mar 12]. Available http://www.fbi.gov/hq/cid/orgcrime/glossary.htm.

[8] Liddick DR. An empirical, theoretical and historical overview of organised crime. Lewiston: Edwin Mellen Press; 2009.

[9] Albanese JA. A criminal network approach to understanding and measuring trafficking in human beings: Complexities and Pitfalls. New York: Springer; 2007.

[10] Roth MP. Organised Crime. Upper Saddle River: prentice Hall; 2010.

[11] Finckenauer JO. Organised Crime in North America. Thousand Oaks: Sage Publication; 2005.

[12] Richards JR. Transnational criminal organisations, cybercrime and money laundering: A handbook for law enforcement officers, auditors and financial investigators. Boca Raton: CRC Press; 1999.

[13] Mallory SL. Understanding Organised Crime. 2nd ed. Sudbury: Jones and Barlett Publishers; 2012.

[14] Caiden GE, Alexander HE. The Politics and Economics of Organised Crime. Massachusetts: Lexington Press; 1985.

[15] Maltz MD. Defining Organised Crime: The development of a definition and a typology. London: Routledge; 2010.

[16] Hagan FE. Organised Crime: Critical Concepts in
Criminology. London: Routledge; 2010.

[17] Carter DL. International Organised Crime: Emerging Trends in Entrepreneurial Crime. New York: Sage Publications; 1997.

[18] Nair PM. Combating Organised Crime. New Delhi: Konark; 2002.

[19] Marion NE. Government versus Organised Crime. New Jersey: Pearson Prentice Hall; 2008.

[20] Roelofse CJ, Oliver C, Kgosimore DL. Organised Crime and Other Criminal Justice Issues in Africa. Mankweng: ACJUS; 2012.

[21] Albanese JS, Das DK, Verma D. Organised Crime. New York: Prentice Hall; 2003.

[22] Swart L. Organised Crime and Other Criminal Justice Issues in Africa. Paper presented at AFCJS 2009. Proceedings of the Conference of All Africa Criminal Justice Society; 2009 Jun 26-29; Polokwane, South Africa. AFCJS; 2009.

[23] Burger J. A Dysfunctional SAPS Intelligence Division has severe implication for reducing crime. Pretoria: Institute for Security Studies; 2012.

[24] Newham G. Protector or Predator? Tackling Police Corruption in South Africa. Monograph 182. Pretoria: Institute for Security Studies; 2011.

[25] Stassen W. Who is to blame for flourishing illegal cigarette trade? 2013 [cited 2013 Jul 16]; Available from: http://www.health-e.org.za/2013/06/13/who-is-to-blame-forflourishing-illegal-cigarette-trade/.

[26] International Consortium of Investigative Journal. Organised Crime. 2001 [cited 2002 Jul 16]; Available from: http://www.icij.org/about.

[27] Minnaar A. A Symbiotic Relationship? Organised Crime and Corruption in South Africa. Paper presented at IACC 1999. Proceedings of the 9th International Anti-corruption conference; 1999 Oct 10-15; Durban, South Africa; 1999. 